\title{
Researches Using Radio-labelled Insecticides in Korea
}

\author{
Kyu-Seung Lee* \\ Dept. of Agriculture Chemistry, Chungnam National University, Daejeon 305-764, Korea \\ (Received December 3, 2007, Accepted December 25, 2007)
}

\begin{abstract}
The scientific articles using radio labelled insecticides performed by Korean researchers were reviewed. The research works were divided into 4 categories such as soil, plant, animal and insect. All researches used ${ }^{14} \mathrm{C}$-labelled chemicals, and the ${ }^{14} \mathrm{C}$-carbofuran was widely used among them. Fate of insecticides, bound-residues and metabolic process were staple conceming area in soil study. And the uptake and translocation, metabolism and metabolites also a major interests in plant study. As well as the degradation, metabolic pathway and metabolites, and distribution of chemicals in animal tissue were another point of consideration in animal study. And finally, the penetration ratio into body and resistant mechanism were the major conceming views of study with insects
\end{abstract}

Key Words: radiolabeled insecticiedes, Korean researches, soil, plant, animal, insect

\section{INTRODUCTION}

Radioactive isotope (RI) technique has widely been used in many fields of sciences and given a big advantage. In pesticide sciences, the RI technique has used widely to know the mode of action, fates and metabolism in plants, animals and environments, also absorption and translocation into the target objectives. ${ }^{14} \mathrm{C}$-labelled pesticides are really powerful weapons for performing above researches. Because they can be detected in an extremely small quantity. The least significant levels of determination are usually $10^{-1}$ to $10^{-2}$ of GC analysis. Also RI labelled compounds are distinguished from plant and animal constituents, and other environmental materials. Furthermore, RI is essential for identification of metabolic products in plant, animal and soil samples, and possible to propose the metabolic pathway of chemicals. In this purpose autoradiograph technique is a very good tool to provide visible and semi-quantitative patterns of pesticide distribution and accumulation. In this paper, the research works with radio labelled insecticides which carried out by the Korean researchers were

*Corresponding author:

Tel: +82-42-821-6735 Fax: +82-42-822-5781

E-mail: kslee@cnu.ac.kr reviewed. Researches were divided into 4 categories including soil, plant, animal and insect. Most researches for soil were interested in the distribution of residues in organic soluble and water soluble fractions, and bound residues, too. Some papers investigated the metabolites and proposed the metabolic pathway. Papers which studied with animals, rat and carp usually considered the fates and transformation of pesticides, too. Several papers dealt with plants, and they focused on the metabolic process and uptake of chemicals. Also, researches with insects were concentrated to resistance mechanisms.

Soil

Kim $(1985)^{1)}$ studied with ${ }^{14} \mathrm{C}$-diazinon to know the fate under paddy soil condition. The total radioactivity was $50.3 \%$ in extractable and $13.9 \%$ in non-extractable fraction at day 1, while it was changed $30.2 \%$ and $36.6 \%$ at 10 days after treatment, respectively. He also investigated the metabolite formation by time course. The only metabolite detected was pyrimidinol (2isopropyl-4-methyl-6 -hydroxypyrimidine).

Lee $(1985)^{2)}$ also studied with ${ }^{14} \mathrm{C}$-diazinon, and he observed the change of total radioactivity in soil dividing extractable and non-extractable fractions until 9 days by time course. Also, he compared two different 


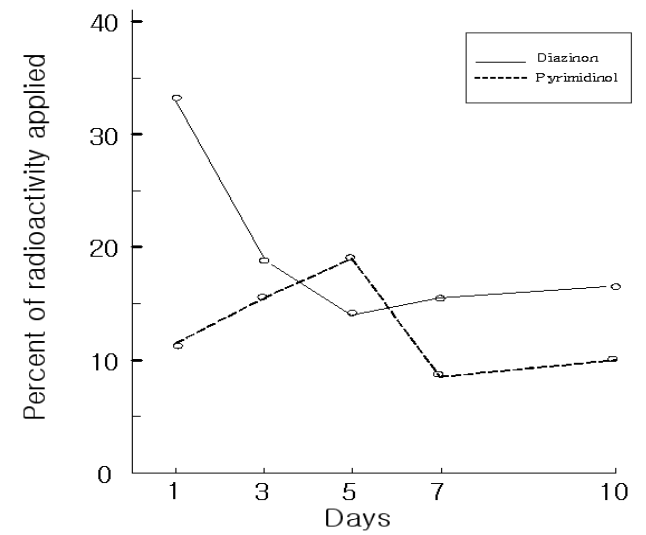

Fig. 1. Degradation pattern of diazinon in paddy soil by time course.

$\operatorname{Kim}(1985)^{1)}$ soil conditions as sterilized and non-sterilized. In the non-sterilized soil, ${ }^{14} \mathrm{C}$-diazinon showed lower radioactivity than sterilized one. The results are shown in Table 1.

Park and Oh (1986) ${ }^{3)}$ studied the fate of ${ }^{14} \mathrm{C}$ - labelled carbofuran in paddy soil.

They compared the total radioactivities from extractable and non-extractable fractions in soil by incubation time, and the extractable fraction devided into organic and aqueous phase. The results showed in Table 2.

As shown in Table 2 the total radioactivities in extractable fraction showed much higher than nonextractable, and almost all of them were in organic phase. Then, gradually the total radioactivities in non-extractable fraction was increased by time course.

Table 1. Distribution of radioactivities following application of ${ }^{14} \mathrm{C}$-diazinon into the non-sterilized soil and sterilized soil

\begin{tabular}{|c|c|c|c|c|c|}
\hline \multirow{3}{*}{$\begin{array}{c}\text { Incubation } \\
\text { period (days) }\end{array}$} & \multicolumn{5}{|c|}{ Radioactivity (\%) } \\
\hline & \multicolumn{5}{|c|}{ Non-sterilized } \\
\hline & $\begin{array}{c}\text { Extrac- } \\
\text { ted }\end{array}$ & $\begin{array}{l}\text { Nonext- } \\
\text { racted }\end{array}$ & $\begin{array}{l}\text { Volatile } \\
\text { fraction }\end{array}$ & $\begin{array}{l}\text { Carbon } \\
\text { dioxied }\end{array}$ & $\begin{array}{l}\text { Reco- } \\
\text { very }\end{array}$ \\
\hline 1 & 44.3 & 11.4 & 0.4 & 0.1 & 56.2 \\
\hline 2 & 37.2 & 14.2 & 2.6 & 0.3 & 54.3 \\
\hline 4 & 32.5 & 25.3 & 1.2 & 0.2 & 59.2 \\
\hline 9 & 25.4 & 32.9 & 1.8 & 0.8 & 60.9 \\
\hline \multirow{3}{*}{$\begin{array}{l}\text { Incubation } \\
\text { period (days) }\end{array}$} & \multicolumn{5}{|c|}{ Radioactivity (\%) } \\
\hline & \multicolumn{5}{|c|}{ Sterilizedd } \\
\hline & $\begin{array}{c}\text { Extrac- } \\
\text { ted }\end{array}$ & $\begin{array}{l}\text { Nonext- } \\
\text { racted }\end{array}$ & $\begin{array}{l}\text { Volatile } \\
\text { fraction }\end{array}$ & $\begin{array}{l}\text { Carbon } \\
\text { dioxied }\end{array}$ & $\begin{array}{l}\text { Reco- } \\
\text { very }\end{array}$ \\
\hline 1 & 54.5 & 15.5 & 1.1 & & 71.1 \\
\hline 2 & 46.9 & 23.2 & 1.9 & 0.5 & 72.5 \\
\hline 4 & 41.3 & 36.5 & 2.4 & 0.1 & 80.3 \\
\hline 9 & 33.7 & 39.6 & 1.1 & 0.5 & 74.9 \\
\hline
\end{tabular}

Table 2. Distribution of radioactivity in extractable and non-extractable fractions in paddy soil by incubation time course treated with ${ }^{14} \mathrm{C}$-carbofuran

\begin{tabular}{cccc}
\hline \multirow{2}{*}{$\begin{array}{c}\text { Incubation } \\
\text { period (day) }\end{array}$} & \multicolumn{2}{c}{ Extractable } & Non-extractable \\
\cline { 2 - 4 } & Organic phase & Aqueous phase & 3.5 \\
1 & 82.9 & 0.6 & 9.2 \\
3 & 63.8 & 1.2 & 14.9 \\
5 & 51.2 & 0.9 & 29.2 \\
9 & 30.0 & 0.8 & 22.4 \\
15 & 19.9 & 0.7 & 24.6 \\
24 & 16.6 & 2.0 & 1.7 \\
\hline
\end{tabular}


The only $4.6 \%$ were existed in extractable fraction in 24 days after application, but $31.7 \%$ in non-extractable fraction in the same day. Also they found several metabolites from paddy soil such as 7-benzofuranol, 3-ketobenzofuranol, 3-hydroxybenzofuranol, 3-ketocarbofuran, 3-hydroxy carbofuran and carbofuran itself, too. They have also investigated the aglycones from conjugated fraction. The conjugates hydrolysed by $\mathrm{HCl}$ and cellulase. By $\mathrm{HCl}$ hydrolysis 7-benzofuranol was the major aglycone (69.2\%) and 3-hydroxy benzofuranol and 3-hydroxycarbofuran in turn. While, carbofuran was the major aglycone $(47.3 \%)$ in cellulase treatment.

Lee et al. (1987) $)^{4)}$ also studied a similar research with Park and Oh (1986) ${ }^{23)}$. They observed the change of total radioactivity in extractable and non-extractable fractions in soil. In extractable fraction, most of the total radioactivity existed in organic phase, and reduced by time course. During 20 days, total radioactivity in organic phase changed from $100.3 \%$ to $11.7 \%$, contrarily it was increased from $0.4 \%$ to $56.3 \%$ in non-extractable fraction, Also, they found carbofuran and its metabolites from organic soluble extracts. And they considered the total radioactivities of non-extractable fraction as the sum of radioactivites in different organic matter fraction such as different organic matter fractions such as fulvic acid, humic acid and humin. The results showed in Table 3.

Lee and Oh (1993) $)^{5)}$ studied the possibility of ground water contamination by pesticides with a loam soil column system for ${ }^{14} \mathrm{C}$-carbofuran. The soils used in this experiment were fresh, 3-month aged and 6-month aged with ${ }^{14} \mathrm{C}$-labelled carbofuran under aerobic condition. The leaching behavior of ${ }^{14} \mathrm{C}$-carbofuran was shown in Table 4. Also they observed the formation of non-extractable bound residues by leaching process in fresh soil, $93.56 \%$ of total radioactivity was extractable before leaching, and 19.18\% was after leaching process. Similarly, $55.09 \%$ and $6.60 \%$ in 3-month aged soil, and $41.26 \%$ and $4.66 \%$ in 6-month aged soil, respectively. And so, the bound residues were formed to $8.33 \%$ and $75.72 \%$ in fresh soil before and after leaching process, respectively. Accordingly, 37.92\% and 85.23\% in 3-month-aged soil and $54.63 \%$ and $92.73 \%$ in 6-month-aged soil. The results showed in Table 4.

Lee $(1993)^{6)}$ also studied with ${ }^{14} \mathrm{C}$-carbofuran. He investigated absorption and mobility characteristics to elucidate the behavior in soil environment. He compared 5 different soils and found the recovered radioactivity of $87.9 \sim 99.3 \%$ in eluted fraction and $1.2 \sim 8.9 \%$ in soil by column chromatographic process. And he also calculated Friundlich adsorption isotherm and distribution coefficient $\left(\mathrm{K}_{\mathrm{d}}\right)$ with 5 different soils,

Table 3. Distribution of non-extractable radioactivity using ${ }^{14} \mathrm{C}$-carbofuran in paddy soil with different organic matter fractions by time course.

\begin{tabular}{cccccccc}
\hline \multirow{2}{*}{ Organic fraction } & \multicolumn{7}{c}{ Radioactivity $^{\text {recovered }}{ }^{1)}(\%)$} \\
\cline { 2 - 8 } & 1 & 3 & 5 & 7 & 10 & 15 & 20 \\
\hline fulvic acid & 38.6 & 35.8 & 32.1 & 34.5 & 33.6 & 31.9 & 31.8 \\
humic acid & 9.0 & 9.2 & 9.1 & 9.3 & 10.1 & 10.4 & 11.3 \\
humin & 52.4 & 55.0 & 58.8 & 56.2 & 56.3 & 57.7 & 56.9 \\
\hline
\end{tabular}

1) Total radioactivity in non-extractable fraction was $100 \%$.

Lee et al. $(1987)^{4)}$

Table 4. Leaching behavior of ${ }^{14} \mathrm{C}$-carbofuran in soil column system

\begin{tabular}{cccccccc}
\hline & \multicolumn{7}{c}{ Radioactivity (\%) $^{1)}$} \\
\cline { 2 - 7 } Treatment & \multicolumn{3}{c}{ Soil segment } & \multicolumn{2}{c}{ Percolate fraction $^{2)}$} & Total \\
& $0-10$ & $10-20$ & $20-30$ & I & II & III & Recovery \\
\hline Fresh & 2.54 & 2.28 & 1.42 & 68.62 & 20.94 & 2.04 & 93.38 \\
3-month-aged & 38.23 & 4.29 & 2.11 & 37.00 & 18.55 & 3.45 & 103.63 \\
6-month-aged & 53.58 & 5.35 & 2.10 & 20.77 & 13.62 & 3.20 & 98.62 \\
\hline
\end{tabular}

1) Applied radioactivity regarded as $100 \%$.

2) I, II, III means that the leachate collected during the 1st month (I), the 2nd month (II) and the 3rd month (III). Lee and Oh $(1993)^{5)}$ 
Friundlich adsorption constant $(\mathrm{K})$ ranged 0.33 to 2.10 , and $K_{d}$ value ranged 0.20 to 1.35 . Specially the volcanic soil showed high $K$ and $K_{d}$ value in all cases. He also carried out TLC and compared Rf value of ${ }^{14} \mathrm{C}$-carbofuran with 5 different soils. Depending on the soil characteristics the Rf value was slightly different to each other.

Lee and Park $\left(1995^{\mathrm{b}}\right)^{7)}$ studied with ${ }^{14} \mathrm{C}$-carbofuran under submerged and upland conditions. They observed the distribution of radioactivity and degradation products by time-course. In submerged condition, the total radio activity in extractable portion changed from $98.3 \%(0$ day) to $56.9 \%$ (60 day) and in non-extractable from $0.5 \%$ to $24.2 \%$, respectively. While under upland condition it was changed from $101.7 \%$ to $47.3 \%$ in extractable portion and $0.2 \%$ to $39.35 \%$ in non-extractable portion. Also, they reported the non- extractable radioactivity was mainly located in soil organic matter in an order of fulvic acid $>$ humin $>$ humic acid.

Lee et al. (1995) $)^{8)}$ carried out a research with ${ }^{14} \mathrm{C}$-acrinathrin, a pyrethroid insecticide, to elucidate the fate of the residues in soil. Two different conditions of soil were used in their experiment, such as fresh and 1-month aged. They found no significant differences of residual patterns between two different conditions of soil. And they proposed a metabolic pathway based on the confirmation of degradable products in soil. (Fig. 2)

Lee et al. $\left(1995^{\mathrm{b}}\right)^{9)}$ also studied with ${ }^{14} \mathrm{C}$-acrinathrin. They investigated the half-lives of ${ }^{14} \mathrm{C}$-acrinathrin were 13 22 days by two different soil types. Also, they found the total radioactivity remaining in soil were $23.63 \sim 37.58 \%$, and ${ }^{14} \mathrm{C}-\mathrm{CO}_{2}$ was recovered $61.62 \sim 81.03 \%$ after 24 weeks of treatment. They observed that the degradation rate of ${ }^{14} \mathrm{C}$-acrinathrin was increased proportional to the soil temperature between $15 \sim 30 \%$.

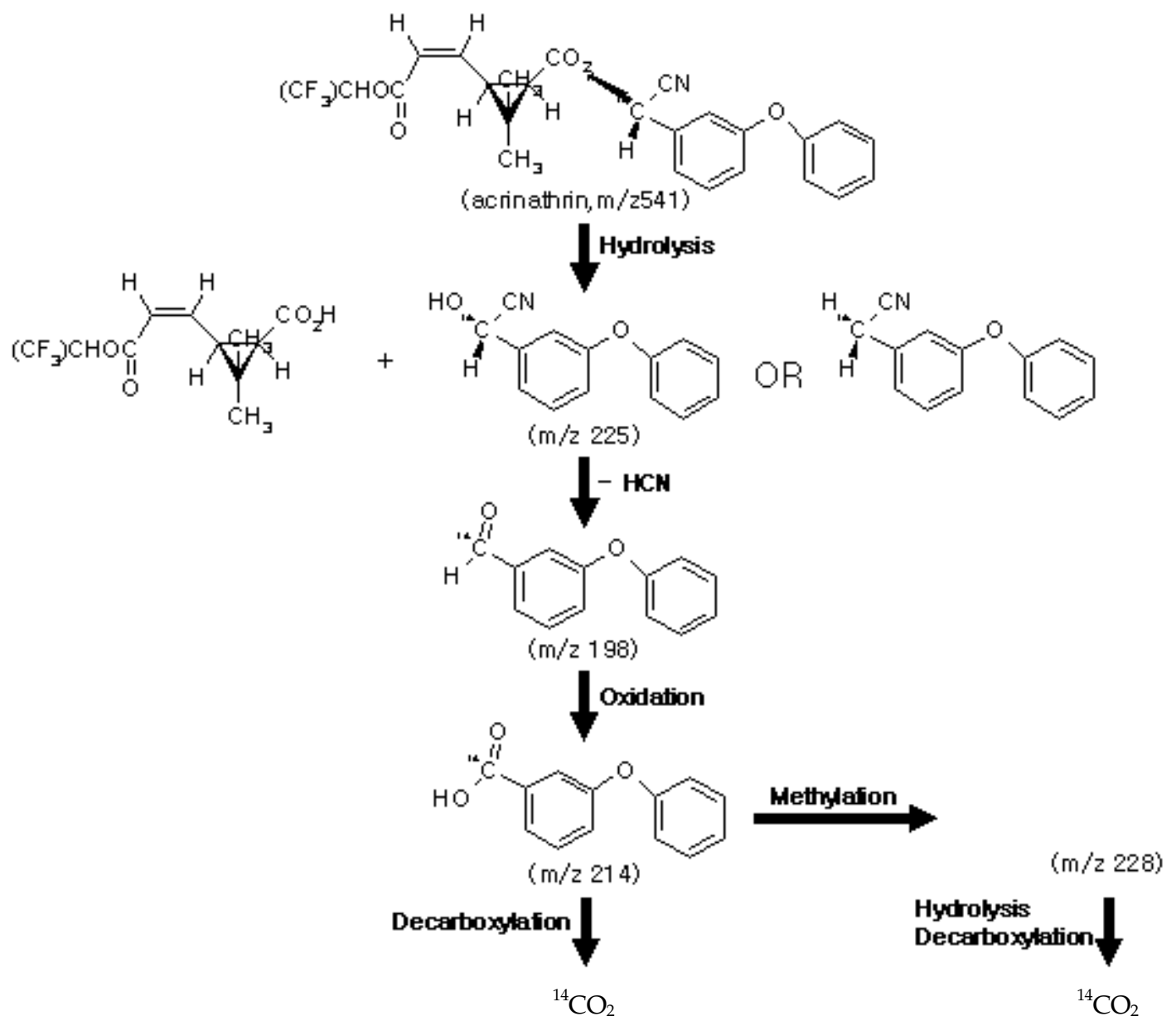

Fig. 2. Possible pathway of ${ }^{14} \mathrm{C}$-acrinathrin degradation in soil. 
After 24 weeks of treatment they extracted the ${ }^{14} \mathrm{C}$-acrinthrin with acetone and found $23.19 \sim 24.61 \%$ of total radioactivity in extractable fraction and 71.53 71.92\% in non-extractable fraction. Also they identified several metabolites using autoradiography and mass spectrometry. The identified metabolites were 3-phenoxybenzoic acid, 3-phenoxybenzaldehyde and methyl 3-phenoxybenzoate.

In 1998, Kim et $\mathrm{al}^{10)}$ reported about aerobic soil metabolism of flupyrazofos, a new phosphorothionate insecticide developed by Korea Research Institute of Chemical Technology (KRICT). They observed the material balance in soil during 60 days, and then they found the solvent-extractable fraction ranged 99\% (0 day) to $50 \%$ (60 days), and non-extractable fraction was $31.6 \%$ (60 days), also the evolution of ${ }^{14} \mathrm{C}-\mathrm{CO}_{2}$ increased gradually and slowly to $5.3 \%$ (60 days). Also, they identified some metabolites by time course, and proposed the metabolic pathway.

Ihm et al. (2006) ${ }^{11)}$ studied with ${ }^{14} \mathrm{C}$-Imidacloprid, a neonicotinoid insecticide, to elucidate the adsorption and leaching characteristics in two types of paddy

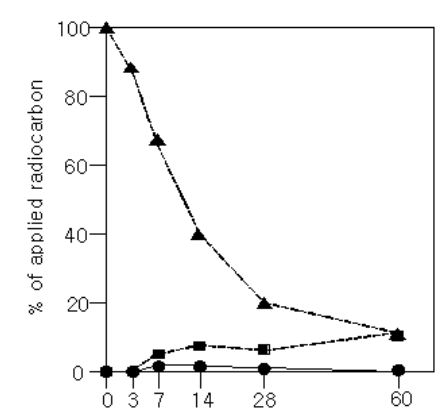

Fig. 3. (A) Degradation of ${ }^{14} \mathrm{C}$-flupyrazofos and formation

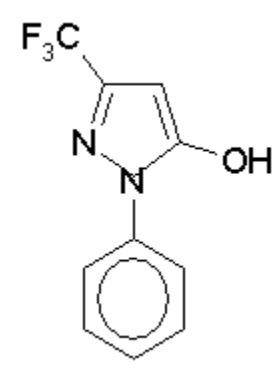

<PTMH : 1-phenyl-3-of (O) flupyrazofos oxon and PIMH trifluoromethyl5-hydroxypyrazole>

Kim et al (1998) ${ }^{10)}$ soils. The adsorption coefficient was ranged $\mathrm{k}_{\mathrm{f}}$ 1.7 2.6, Half-lives were 10 27 days, and Koc were 228 249, also, GUS (Groundwater Ubiquity Score) Index were 1.61 2.35. By soil column experiment, imidacloprid leached less than $2 \%$ during 4 weeks, and $80 \%$ of total radioactivity existed in top soil layer $(0 \sim 10 \mathrm{~cm})$.

Plant

Most of the researches using radio labelled insecticides were focused on rice plant.

Lee and Kim (1981) ${ }^{12)}$ carried out a pot experiment with ${ }^{14} \mathrm{C}$-BHC. They treated on soil surface with ${ }^{14} \mathrm{C}-\mathrm{BHC} 64$ days before harvest. At harvest time the radioactivity was found in all part of rice plant like root, straw, leaves and grain. The total recovery of ${ }^{14} \mathrm{C}$-activity was $2.42 \%$ in rice straw, $0.26 \%$ in brown rice and $0.10 \%$ in rice hull. Also they polished the brown rice, and compared the total radioactivity in polished rice and rice bran distributing to the ratio of $88: 12$. They also prepared oil with rice bran and compared total radioactivity in oil and oil cake partitioning the ratio of 37:63. Hence, they observed the metabolites of ${ }^{14} \mathrm{C}$-BHC and identified $\mathrm{r}$-BHC in rice straw and pentachlorocyclohexane in brown rice.

Kim $(1985)^{1)}$ sprayed ${ }^{14}$ C-diazinon at the early stage of rice growing by water treatment method, and observed the total radioactivity by time course. Also, he found the metabolite, pyrimidinol in shoots. The pyrimidinol contents was increased until day 5 , and then slowly decreased to day 10 . On the day 5 the pyrimidinol content in shoot was about $47.9 \%$ of total radio activity in shoot. Lee $(1985)^{15)}$ reported the total radioactivity in rice plant were slightly increased by time course in case of ${ }^{14} \mathrm{C}$-diazinon to early stage of rice plant. It was $3.3 \%$ in $12 \mathrm{hrs}$ after treatment, $5.4 \%$ at day 4 and $9.6 \%$ at day 9 (Table 5).

Table 5. Change of total radioactivity ${ }^{1)}$ of ${ }^{14} \mathrm{C}$-diazinon in rice plant by time Course.

(\%)

\begin{tabular}{|c|c|c|c|c|}
\hline \multirow{2}{*}{$\begin{array}{l}\text { Days after } \\
\text { treatment }\end{array}$} & \multicolumn{2}{|c|}{ Shoot } & \multirow{2}{*}{$\begin{array}{c}\text { Root } \\
\text { Extractable }\end{array}$} & \multirow{2}{*}{ Total } \\
\hline & Extractable & Non-extractable & & \\
\hline 1 & 15.8 & 1.2 & 3.1 & 20.1 \\
\hline 3 & 23.1 & 0.4 & 4.8 & 28.3 \\
\hline 5 & 19.0 & 0.3 & 3.2 & 22.5 \\
\hline 7 & 19.6 & 0.3 & 3.1 & 23.0 \\
\hline 10 & 18.1 & 0.3 & 3.5 & 21.9 \\
\hline
\end{tabular}

1) Total applied radioactivity is $100 \%$. 
Park and Oh $(1986)^{3)}$ treated ${ }^{14} \mathrm{C}$-carbofuran to rice seedlings and they found the radioactivity in whole rice plants at few hours after treatment by autoradiograph. The distributable fractions in shoots and roots of rice plants were summarized in Table 6. From Table 6 we could know the total radioactivity in rice plants was gradually increased. In shoot until 5 days after treatment, radioactivity in organic phase showed higher than in aqueous phase + non-extractable, while 9 days after treatment the ratio was converted completely. This phenomenon might exist due to phase 1 and phase 2 reaction in rice plants. Because the nonpolar carbofuran in organic phase changed to polar metabolites in aqueous phase and conjugated into non-extractable fraction. They also identified some metabolites in shoots and roots, and revealed 3-hydroxy carbofuran was the major metabolite at 24 days after application.

Lee et al. (1987) ${ }^{4)}$ also studied with ${ }^{14} \mathrm{C}$-carbofuran with rice seedlings. And they found that carbofuran reached shoot tips and accumulated within 2 days. Also, more than $15 \%$ of total radioactivity was recovered in rice plant from 3 to 20 days after treatment. In organic fraction of rice plant extract, 3-hydroxycarbofuran was the major metabolite recording $43 \%$ and $4 \%$ of total organic soluble radioactivity in shoot and root at 20 days, respectively. Also, 3-ketocarbofuran and phenolic metabolites including carbofuran phenol, 3-hydroxycarbofuran phenol and 3-ketocarbofuran phenol were detected in organic soluble fractions. Some glycosidic conjugates of carbofuran metabolites were found in water soluble fraction of rice plant extract, and 3-hydroxycarbofuran was the most abundant aglycone.

Lee $(1993)^{13)}$ carried out a water culture experiment with rice seedlings (30-day old) using ${ }^{14} \mathrm{C}$-carbofuran. He applied ${ }^{14} \mathrm{C}$-carbofuran into the cultivating solution. The rice plants absorbed rapidly by root and readily translocated to the shoot. The absorption pattern showed linearity by time course, and it seemed passively associated with water transpiration of rice plants.

He also mentioned about the distribution of radioactivity in different fraction such as organic soluble, water soluble non-extractable. In rice shoot, those three fractions were getting increased by time course with the order of organic soluble> non-extractable> water soluble, and at 5 days after treatment total

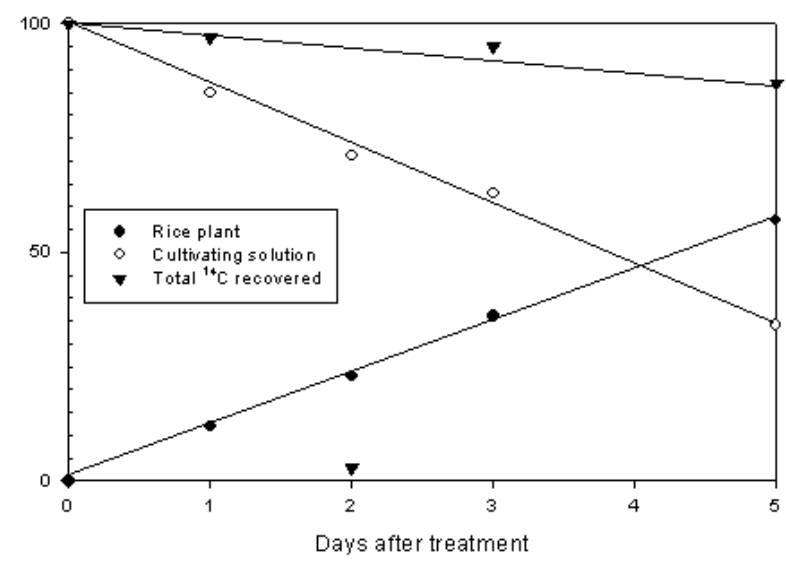

Fig. 4. Change in the distribution of radioactivity between rice plants and cultivating solution after treatment of $\left[{ }^{14}\right.$ C]carbofuran.

Lee $(1993)^{13)}$

Table 6. Distribution of radioactivity in extractable and non-extractable fraction following application of C- ${ }^{14}$ labelled carbofuran

\begin{tabular}{|c|c|c|c|c|c|c|c|}
\hline \multirow{4}{*}{$\begin{array}{l}\text { Incubation } \\
\text { Period } \\
\text { (day) }\end{array}$} & \multicolumn{7}{|c|}{ Radioactivity (\%) } \\
\hline & \multicolumn{3}{|c|}{ Shoots } & \multicolumn{3}{|c|}{ Roots } & \multirow{3}{*}{ Total } \\
\hline & \multicolumn{2}{|c|}{ Extractable } & \multirow{2}{*}{$\begin{array}{c}\text { Non- } \\
\text { extractable }\end{array}$} & \multicolumn{2}{|c|}{ Extractable } & \multirow{2}{*}{$\begin{array}{c}\text { Non- } \\
\text { extractable }\end{array}$} & \\
\hline & $\begin{array}{c}\text { Organic } \\
\text { phase }\end{array}$ & $\begin{array}{c}\text { Aqueous } \\
\text { phase }\end{array}$ & & $\begin{array}{c}\text { Organic } \\
\text { phase }\end{array}$ & $\begin{array}{l}\text { Aqueous } \\
\text { phase }\end{array}$ & & \\
\hline 0.1 & 0.3 & 0 & 0 & 0.2 & 0 & 0.1 & 0.7 \\
\hline 1 & 5.0 & 1.9 & 1.5 & 1.3 & 0.1 & 0.6 & 11.4 \\
\hline 3 & 7.4 & 1.9 & 2.7 & 0.9 & 0.4 & 1.0 & 17.3 \\
\hline 5 & 14.8 & 1.4 & 3.8 & 0.7 & 0.1 & 4.9 & 30.7 \\
\hline 9 & 7.4 & 7.3 & 10.7 & 0.2 & 0.2 & 2.3 & 37.1 \\
\hline 15 & 4.3 & 4.1 & 15.1 & 0.3 & 0.3 & 1.2 & 40.3 \\
\hline 24 & 1.6 & 6.0 & 14.1 & 0.1 & 0.1 & 4.1 & 50.0 \\
\hline
\end{tabular}


radioactivity recovered about $45 \%$. While in rice root the absorbtion pattern was much similar with shoot, and the total radioactivity recovered at 5 days after treatment was only about $10 \%$.

Lee et al. $(1995)^{8)}$ treated to maize plant with ${ }^{14} \mathrm{C}$-acrinathrin. They planted maize seedlings into pot and cultivated for 30 days. The total ${ }^{14} \mathrm{C}$-activity absorbed and translocated into maize ranged $0.18 \% \sim 0.37 \%$ in roots, and $0.04 \sim 0.05 \%$ in soots, respectively.

Lee et al. (1993) ${ }^{14)}$ worked with ${ }^{14} \mathrm{C}$-phosphamidon treated to pine trees controlling pine leaf gall midges (Thecodiplosis japonensis Uchida et Inouye). ${ }^{14} \mathrm{C}$-phosphamidon was implanted into the trunks of 10-years-old korean red pine (Pinus densiflora Sieb. et Zucc) and Japanese black pine (Pinus thunbergic Parl.), respectively. Japanes black pine was treated with ${ }^{14} \mathrm{C}$-phosphamidon in December as usual, and Korean red pine was treated in July for effective control of pine leaf gall midges. The upward movement rates of the chemical within Korean red pine in July and Japanese black pine in December were ca. $10 \mathrm{~cm} / \mathrm{hr}$ and $2 \mathrm{~cm} / \mathrm{hr}$, respectively. And the lower branch showed higher concentration than that of the higher branches. The original radioactivity level maintained up to 75 days after treatment throughout the whole tree in Korean red pine, whereas it did up to 150 days in Japanese black pine. The chemical was translocated up to the top at the insecticidal level within 3 days in July, and 15 days in December. From the methanol extraction of pine needles, the phosphamidon broke down very quickly, about $80 \%$ of applied concentration metabolized within 7 days.

They also investigated $\left(1993^{\mathrm{b}}\right)^{15)}$ the metabolism of ${ }^{14} \mathrm{C}$-phosphamidon in pine trees. As confirmed by TLC autoradiography and GC/MS the major metabolites in pine needles were a-chloroacetoacetic acid, diethylamide, a-chloroacetoacetic acid ethylamide, 3-hydroxy-N,Ndiethylbutanamide, acetoacetamide, and trimethyl phosphated. They also proposed the metabolic pathway based on the identified metabolites.

\section{Animal}

Usually the rat is the most convenient animal for animal metabolism of chemicals and toxicity test, while carp also used widely for the aquatic toxicity.

Kim et al. (1995) ${ }^{16)}$ studied in vitro metabolism of ${ }^{14} \mathrm{C}$-endosulfan by liver and kidney microsomal cytochrome P-450 monooxygenase system of the mouse (Balb. c). They found several metabolites such as endosulfan lactone (EL), endosulfan hydroxyether (EME), endosulfan alcohol (EA), endosulfan sulfate (ES) and $\beta$-endosulfan ( $\beta$-E). With liver microsome EL (13.2\%) and EA (11.5\%) were major metabolites, whereas EA $(17.4 \%)$ and EME $(19.3 \%)$ in kidney microsome. Especially in water soluble fraction EA (83.9\%), EME $(4.5 \%)$ and ES $(2.3 \%)$ were found as the metabolites. Piperonyl butoxide (PBO) treatment inhibited the formation of $\mathrm{EE}$ to $86 \%$ EA to $92 \%$ and other metabolites were barely formed. Hence, they concluded a-endosulfan could be metabolized cytochrome p-450 system in rat liver and kidney.

Kim et al. (1996) ${ }^{17)}$ also studied with male mouse (Balb/c) with ${ }^{14} \mathrm{C}$-endosulfan by intraperitoneal injection method. They carried out the research to know absorption, distribution, excretion and metabolism of a-endosulfan in mouse. After single treatment of 7.5 $\mathrm{mg} \cdot \mathrm{kg}^{-1}$ body weight basis, they found $63.9 \%$ of the total radioactivity excreted in urine within 4 days. Also, they observed the distribution of radioactivity through mouse tissues (liver, kidney and heart) with time course (Table 8).

Radioactivity levels in the tissues were reached to maximum at $0.5 \mathrm{hr}$ in heart, $2 \mathrm{hrs}$ in liver and kidney after treatment. The main metabolite was endosulfan alcohol (13.25\%) in liver and endosulfan hydroxyether $(19.37 \%)$ in kidney, and urinary metabolites were

Table 7. Translocation velocity of ${ }^{14} \mathrm{C}$ - Phosphamidon in Korea red pine and Japanese black pine

\begin{tabular}{ccccc}
\hline \multirow{2}{*}{ Tree } & Height $(\mathrm{m})$ & $\begin{array}{c}\text { Day taken for } \\
\text { detection of }{ }^{14} \mathrm{C} \\
\text { at top }\left(\mathrm{DAT}^{*}\right)\end{array}$ & $\begin{array}{c}\text { Maximum velocity } \\
(\mathrm{cm} / \mathrm{hr})\end{array}$ & Time treated \\
\hline Korean red pine & 1.5 & 0.5 & 12.5 & July, 1990 \\
\cline { 2 - 5 } & 2.3 & 1 & 9.6 & July, 1991 \\
\hline Japanese black pine & 3.5 & 7 & 2.1 & Lee et al (1993) $^{14)}$ \\
\hline
\end{tabular}


endosulfan alcohol (43.2\%), endosulfan hydroxyether (18.04\%), $\beta$-endosulfan (7.21\%), endosulfan sulfate (4.78\%) and endosulfan ether $(3.72 \%)$, in turn.

Han and Rim (1998) ${ }^{18)}$ studied the effect of phenobarbital sodium (PB) and 3-methylcholanthrene (3-MC) on metabolism in vivo and toxicity of ${ }^{14} \mathrm{C}$-carbofuran with rat. They treated carbofuran alone, and combination with $\mathrm{PB}$ and 3-MC to rat, and the $\mathrm{LD}_{50}$ (96 hrs) value of carbofuran determined $6.9 \mathrm{mg} \cdot \mathrm{kg}^{-1}$. And they found that the survival ratio of rat was null at the dose of $8.4 \mathrm{mg} \cdot \mathrm{kg}^{-1}$ body weight of rat. when they treated $20 \mathrm{mg}$. $\mathrm{kg}^{-1}$ of $\mathrm{PB}$ or 3-MC, the survival ratio increased up to $60 \sim 80 \%$, and $100 \%$ with $60 \mathrm{mg} \cdot \mathrm{kg}^{-1}$ of $\mathrm{PB}$ or $3-\mathrm{MC}$. It was clear that $\mathrm{PB}$ and 3-MC reduced the toxicity of carbofuran. They also carried out in vivo experiment with rat liver microsomal and soluble fraction to know the phase I and phase II metabolism and metabolites.

From Table 9 PB and 3-MC could be affected to the monooxygenase (MO) activity of liver microsome, so non-toxic metabolite (3-keto carbofuran) formed very quickly. While phase II reaction was not much affected by $\mathrm{PB}$ and 3-MC.

Rim and Han (2002) ${ }^{19)}$ also reported about the effects of $\mathrm{PB}$ and 3-MC on in vivo metabolism of ${ }^{14} \mathrm{C}$-carbofuran with rat. They observed the change of total radioactivity in urine and feces and also changed

Table 8. Relative ${ }^{14} \mathrm{C}$-radioactivity in the mouse tissues after ${ }^{14} \mathrm{C}$ - $\alpha$-endosulfan treatment

\begin{tabular}{cccc}
\hline \multirow{2}{*}{ Time after treatment $(\mathrm{hr})$} & \multicolumn{3}{c}{ \% of ${ }^{14}$ C-radioactivity in earch tissue } \\
\cline { 2 - 4 } & Liver & Kidney & Heart \\
\hline $0 \sim 0.5$ & 0.33 & 0.37 & 8.07 \\
$0.5 \sim 1.0$ & 0.43 & 0.63 & 7.17 \\
$1.0 \sim 2.0$ & 1.43 & 0.48 & 6.22 \\
$2.0 \sim 4.0$ & 0.87 & 0.72 & 5.24 \\
$4.0 \sim 8.0$ & 0.55 & 0.31 & 2.44 \\
$8.0 \sim 12$ & 0.18 & $\mathrm{ND}$ & 1.12 \\
$12 \sim 24$ & $\mathrm{ND}$ & $\mathrm{ND}$ & 0.89 \\
$24 \sim 48$ & $\mathrm{ND}$ & $\mathrm{ND}$ & 0.48 \\
$48 \sim 96$ & $\mathrm{ND}$ & $\mathrm{ND}$ & ND \\
\hline
\end{tabular}

Table 9. Metabolites in microsomal fraction of rat liver after $2 \mathrm{hrs}$ incubation with ${ }^{14} \mathrm{C}$-carbofuran

\begin{tabular}{|c|c|c|c|c|c|c|c|}
\hline Chemical & System & $\begin{array}{l}\text { Carbo } \\
\text { furan }\end{array}$ & $\begin{array}{c}\text { 3- } \\
\text { hydroxy } \\
\text { carbofuran }\end{array}$ & $\begin{array}{l}\text { 3- } \\
\text { keto carbo } \\
\text { furan }\end{array}$ & $\begin{array}{c}\text { Carbo } \\
\text { furan phenol }\end{array}$ & $\begin{array}{c}\text { 3- } \\
\text { hydroxy } \\
\text { carbo } \\
\text { furan phenol }\end{array}$ & $\begin{array}{c}3- \\
\text { keto carbo } \\
\text { furan } \\
\text { phenol }\end{array}$ \\
\hline \multirow{2}{*}{$\begin{array}{l}{ }^{14} \mathrm{C}- \\
\text { carbo } \\
\text { furan }\end{array}$} & $\begin{array}{c}\mathrm{NADP}+\mathrm{G}-6-\mathrm{P}^{2)}+\mathrm{DG}^{3)} \\
(\text { phase I) }\end{array}$ & 84.4 & 6.21 & 3.57 & 0.31 & 1.10 & 0.54 \\
\hline & $\begin{array}{l}\text { NADPH+GSH } \\
\text { (phase II) }\end{array}$ & 88.7 & 3.22 & 2.53 & 0.31 & 0.76 & 0.57 \\
\hline \multirow{2}{*}{$\begin{array}{l}{ }^{14} \mathrm{C} \\
- \text { carbo } \\
\text { furan } \\
+ \text { PBD }\end{array}$} & $\begin{array}{c}\mathrm{NADP}+\mathrm{G}-6-\mathrm{P}+\mathrm{DG} \\
\text { (phase I) }\end{array}$ & 52.2 & 3.64 & 36.8 & 0.44 & 1.06 & 0.36 \\
\hline & $\begin{array}{l}\text { NADPH+GSH } \\
\text { (phase II) }\end{array}$ & 76.4 & 5.56 & 8.19 & 1.34 & 1.48 & 0.94 \\
\hline \multirow{2}{*}{$\begin{array}{c}{ }^{14} \mathrm{C}- \\
\text { carbo } \\
\text { furan } \\
+3-\mathrm{MC}^{1)}\end{array}$} & $\begin{array}{l}\mathrm{NADP}+\mathrm{G}-6-\mathrm{P}+\mathrm{DG} \\
\text { (phase I) }\end{array}$ & 29.9 & 5.74 & 59.3 & 0.29 & 1.16 & 0.40 \\
\hline & $\begin{array}{l}\text { NADPH+GSH } \\
\text { (phase II) }\end{array}$ & 80.5 & 4.81 & 9.04 & 1.13 & 2.06 & 0.88 \\
\hline \multicolumn{6}{|c|}{$\begin{array}{l}\text { 2) G-6-P : Glucose-6-phosphate. } \\
\text { 3) DG : Glucose-6-phosphate dehydrogenase. }\end{array}$} & \multicolumn{2}{|c|}{ Han and $\operatorname{Rim}(1998)^{18)}$} \\
\hline
\end{tabular}


in various tissues such as liver, kidney, small intestine, large intestine and blood. $79.9 \% \sim 81.4 \%$ of total radioactivity was excreted by urine and $5.7 \% \sim 6.5 \%$ by feces. Two major metabolites, 3-hydroxy carbofuran and 3-ketocarbofuran were found in urine as $17.4 \%$ and $12.8 \%$, respectively. In case of carbofuran administration only, and by addition to $\mathrm{PB}$ or 3-MC, they were changed to $18.6 \%$ and $23.5 \%$. This phenomena indicated that the oral administration of $\mathrm{PB}$ or 3-MC could reduce carbofuran toxicity in rat.

Lee et al. (1994) ${ }^{20)}$ carried out an in vitro experiment using ${ }^{14} \mathrm{C}$-endosulfan with various tissues of carp (cyprinus caprio). They prepared the microsomal and soluble fractions from liver, kidney and gut. They compared various cofactors affected to the phase I and phase II reaction system. In 105,000 g soluble subcellular fraction of liver phase I system showed higher metabolite formation rates, and the phase II system with NADPH was activated with liver and kidney preparations. Whereas in microsmal fraction of gut the metabolic ability showed higher with GSH or GSH +NADPH than the other tissues. Hence, they suggested that the metabolic processes in liver and kidney governed by MFO system and in gut by GST system. They also identified the metabolites of a -endosulfan, and found endosulfan alcohol, endosulfan ether and endosulfan a-hydroxyether as in the same in vivo study, nevertheless endosulfan sulfate was not identified in any tissues (Fig. 5).
Lee et al. $\left(1994^{\mathrm{b}}\right)^{21)}$ also developed radio- immuno assay (RIA) with ${ }^{14} \mathrm{C}$-endosulfan for the residue analysis in water and carp. They conjugated the hapten of a -endosulfan, endosulfan diol and succinylated BSA as an antigene and prepared endosulfan - specific antibody by injection the antigene to rabbit. 14 weeks after the 1 st injection of antigene, they certified the antibody formation from serum. The produced antibodies showed higher tiers to endosulfan-BSA $(1: 32,000)$. And a RIA method was developed for residue analysis of endosulfan in water and carp using ${ }^{14} \mathrm{C}$-endosulfan as a tracer.

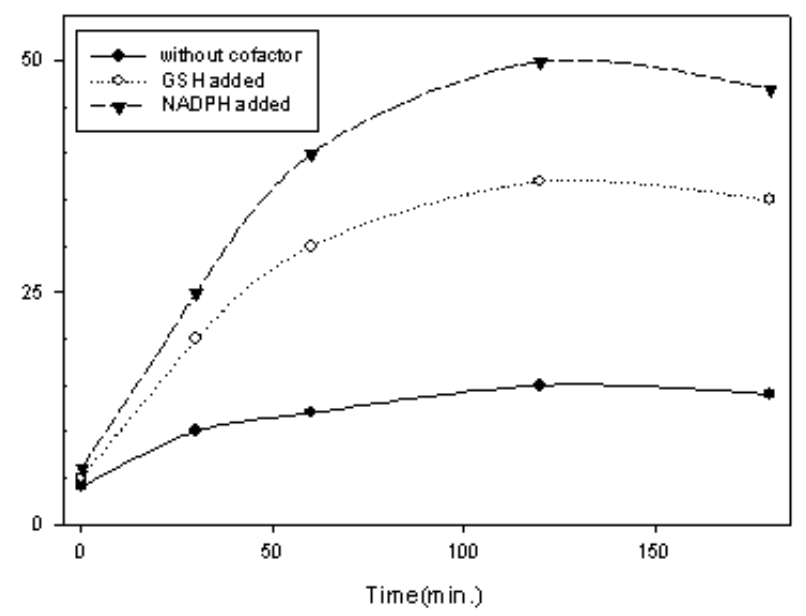

Fig. 5. Formation rate of water-soluble metabolites of ${ }^{14} \mathrm{C}$-endosulfan by the $105,000 \mathrm{~g}$ supernatent of the carp liver homegenate ; $(\mathrm{O})$ without cofactor, $(\mathrm{O}) \mathrm{GSH}$ added, and (A) NADPH added.

Lee et al. $(1994)^{20)}$

Table 10. Relative distribution of organic soluble ${ }^{14} \mathrm{C}$ and water soluble ${ }^{14} \mathrm{C}$ in water and carp

\begin{tabular}{|c|c|c|c|c|c|c|c|}
\hline \multirow{3}{*}{$\begin{array}{l}\text { Exposure } \\
\text { conc. } \\
\left(\mathrm{mg} \cdot \mathrm{L}^{-1}\right)\end{array}$} & \multirow{3}{*}{$\begin{array}{c}\text { Days } \\
\text { after } \\
\text { Exposure }\end{array}$} & \multicolumn{6}{|c|}{ Relative distribution of radioactivity recovered (\%) } \\
\hline & & \multicolumn{2}{|c|}{ Carp } & \multicolumn{2}{|c|}{ Water } & \multicolumn{2}{|c|}{ Water Control } \\
\hline & & $\begin{array}{l}\text { Organic } \\
\text { soluble }\end{array}$ & $\begin{array}{c}\text { Water } \\
\text { soluble }\end{array}$ & $\begin{array}{l}\text { Organic } \\
\text { soluble }\end{array}$ & $\begin{array}{c}\text { Water } \\
\text { soluble }\end{array}$ & $\begin{array}{c}\text { Organic } \\
\text { soluble }\end{array}$ & $\begin{array}{c}\text { Water } \\
\text { soluble }\end{array}$ \\
\hline \multirow{5}{*}{0.1} & 1 & 79.2 & 20.7 & 96.3 & 1.7 & 99.5 & 0.5 \\
\hline & 2 & 67.2 & 32.8 & 97.1 & 2.9 & 99.5 & 0.5 \\
\hline & 3 & 49.6 & 50.4 & 88.5 & 11.5 & 99.5 & 0.5 \\
\hline & 5 & 35.2 & 64.8 & 70.1 & 29.9 & 99.5 & 0.5 \\
\hline & 7 & 16.0 & 84.0 & 38.1 & 61.9 & 99.2 & 0.8 \\
\hline \multirow{5}{*}{0.5} & 1 & 77.4 & 22.6 & 98.2 & 1.8 & 99.6 & 0.4 \\
\hline & 2 & 63.4 & 36.6 & 97.5 & 2.5 & 99.7 & 0.3 \\
\hline & 3 & 58.5 & 41.5 & 93.3 & 6.7 & 99.6 & 0.4 \\
\hline & 5 & 48.5 & 51.5 & 84.2 & 15.8 & 99.6 & 0.4 \\
\hline & 7 & 29.5 & 70.5 & 51.9 & 48.1 & 99.5 & 0.5 \\
\hline
\end{tabular}


Then, they compared the developed RIA, ELISA and GC-ECD analysis. The detection limit of those methods were $0.1 \mathrm{ng} \cdot \mathrm{ml}^{-1}$ in RIA, $2.0 \mathrm{ng} \cdot \mathrm{ml}^{-1}$ in GC-ECD and $5.0 \mathrm{ng} \cdot \mathrm{ml}^{-1}$ in ELISA, respectively.

Shin et al. (1997) ${ }^{22)}$ studied with ${ }^{14} \mathrm{C}$-fenobucarb, a methyl carbamate insecticide to know the uptake, biotransformation and excretion in carp. They added the chemical at the levels of 0.1 and $0.5 \mathrm{mg} \cdot \mathrm{l}^{-1}$ into waterbath, and reared the carp for a week. Water and carp were sampled at 1, 2, 3, 5 and 7 days after treatment, and observed the distribution of total radioactivity, the relative distribution ratio of radioactivity in organic and soluble fractions, and metabolite formation, too. They mentioned that the ratio of the radioactivity between water soluble fraction and organic soluble fraction in water and carp tracts was increased rapidly with time course, and showed higher in carp than in water. Also, they found the total recovered radioactivity decreased with time course and a week after treatment it was less than half of applied ${ }^{14} \mathrm{C}$-radioactivity could be evolved by ${ }^{14} \mathrm{CO}_{2}$ through biotransformation of carp. At least 7 metabolites were detected from organic soluble fraction of water on autoradiogram of TLC plates (Table 10).

\section{Insects}

Lee et al. (1989) ${ }^{23)}$ studied the metabolic fate of trans- $\left[{ }^{[4} \mathrm{C}\right]$ cypermethrin in Heliothis spp. following topical dose. They applied $1.0 \mu \mathrm{l}$ of acetone solution of trans $-\left[{ }^{14} \mathrm{C}\right]$ cypermethrin topically to the dorsal mesothorax using a microsyringe. And a comparison was made between a strain of $H$. armigera and a strain of $H$. virescenes, both of which are susceptible to pyrethroid insecticides. Also, several metabolites were compared with two species. In sixth instar larvae of $H$. armigera more than half of the applied dose was absorbed within $8 \mathrm{hr}$ and most of this appeared as ${ }^{14} \mathrm{C}$-labelled material in excreta within $48 \mathrm{hr}$. The major extracted metabolites were the acids, trans-3-(2,2'-dichlorovinyl)2,2-dimethyl cycloprane carboxylic acid $\left(\mathrm{t}-\mathrm{Cl}_{2} \mathrm{CA}\right)$, trans-hydoxy-trans-3-(2,2-dichlorovinyl) 2,2-dimethylcycloprane carboxylic acid ( $\left.\mathrm{tOH}-\mathrm{Cl}_{2} \mathrm{CA}\right)$, and 2-hydroxytrans-cypermethrin+4-hydroxy-trans-cypermethrin (2'/4'-OH-trans-cypermethrin). Conjugates were also found, and these released 2'/4'-OH-trans-cypermethrin and $\mathrm{t}-\mathrm{Cl}_{2} \mathrm{CA}$ after acid hydrolysis. Thus there was evidence of metabolism by monooxygenase and esterase in both species. And they compared the metabolism with the third instar larvae of the two species during the period $0-8 \mathrm{hr}$ after dosing the insecticides. And they found that $H$. virescens metabolised a higher proportion of the absorbed dose and (ii) produced relatively more of the metabolite $\mathrm{t}-\mathrm{OH}-\mathrm{Cl}_{2} \mathrm{CA}$ than $\mathrm{H}$. armigera did. This suggested the presence of a higher monooxygenase activity towards trans-cypermethrin in $H$. virescens than in $H$. armigara. These differences might contribute to the greater toxicity of $\mathrm{t}$-cypermethrin to $H$. armigera than to $H$. virescens.

McCaffery et al. (1991) $)^{24)}$ reported the results of comparison with the susceptible strain, BRC and

Table 11. Metabolism of trans- $\left[{ }^{14} \mathrm{C}\right]$ Cypermethrin in $H$. armigera and $H$. virescens $8 \mathrm{hr}$ after Topical Application

\begin{tabular}{|c|c|c|c|c|c|c|c|}
\hline & \multicolumn{7}{|c|}{ Ridioactivity (\% of applied dose) } \\
\hline & $\begin{array}{l}\text { Trans- } \\
\text { Cyper } \\
\text { methrin }\end{array}$ & Conjugates & $\mathrm{tOH}-\mathrm{Cl}_{2} \mathrm{CA}$ & $\mathrm{t}-\mathrm{Cl}_{2} \mathrm{CA}$ & $\begin{array}{c}20 ' / 4^{\prime}-\mathrm{OH}- \\
\text { t-cyper }\end{array}$ & $\begin{array}{c}\text { Total } \\
\text { (metabs) }\end{array}$ & $\begin{array}{c}\text { Total } \\
\text { recovered } \\
{ }^{14} \mathrm{C}\end{array}$ \\
\hline \multicolumn{8}{|l|}{ Insect } \\
\hline H. armigera & $\begin{array}{l}5.66 \pm 0.33^{\mathrm{a}} \\
(4.70-6.18)\end{array}$ & $\begin{array}{c}0.69 \pm 0.21 \\
(0.40-1.03)\end{array}$ & $\begin{array}{c}0.21 \pm 0.10 \\
(0.14-0.50)\end{array}$ & $\begin{array}{c}1.15 \pm 0.08 \\
(1.39-1.74)\end{array}$ & $\begin{array}{c}1.45 \pm 0.53 \\
(0.29-2.72)\end{array}$ & $3.97 \pm 0.67$ & $\begin{array}{c}9.45 \pm 0.94 \\
(7.58-11.61)\end{array}$ \\
\hline H. virescens & $\begin{array}{c}1.12 \pm 1.63 \\
(1.94-18.63)\end{array}$ & $\begin{array}{c}1.31 \pm 0.09 \\
(1.09-1.55)\end{array}$ & $\begin{array}{c}1.18 \pm 0.11 \\
(0.90-1.52)\end{array}$ & $\begin{array}{l}3.16 \pm 0.24 \\
(2.62-3.99)\end{array}$ & $\begin{array}{c}0.84 \pm 0.14 \\
(0.52-1.33)\end{array}$ & $6.49 \pm 0.51$ & $\begin{array}{l}7.60 \pm 0.48 \\
(6.00-9.01)\end{array}$ \\
\hline \multicolumn{8}{|l|}{ Excreta } \\
\hline H. armigera & $\begin{array}{c}14.26 \pm 1.63 \\
(10.94-18.63)\end{array}$ & $\begin{array}{c}0.61 \pm 0.09 \\
(0.41-0.83)\end{array}$ & $\begin{array}{c}0.21 \pm 1.10 \\
(0.04-0.50)\end{array}$ & $\begin{array}{l}5.68 \pm 0.72 \\
(4.20-7.61)\end{array}$ & $\begin{array}{c}0.40 \pm 0.21 \\
(0.04-0.95)\end{array}$ & $6.90 \pm 0.48$ & $\begin{array}{c}21.16 \pm 1.69 \\
(17.28-24.94)\end{array}$ \\
\hline H. virescens & $\begin{array}{c}4.36 \pm 0.27 \\
(3.61-5.23)\end{array}$ & $\begin{array}{c}0.36 \pm 0.04 \\
(0.23-0.45)\end{array}$ & $\begin{array}{c}0.77 \pm 0.07 \\
(0.60-0.97)\end{array}$ & $\begin{array}{c}2.22 \pm 0.26 \\
(1.71-3.10)\end{array}$ & $\begin{array}{c}1.12 \pm 0.12 \\
(0.90-1.58)\end{array}$ & $4.47 \pm 0.24$ & $\begin{array}{c}8.83 \pm 0.35 \\
(7.45-9.33)\end{array}$ \\
\hline
\end{tabular}

\footnotetext{
${ }^{\mathrm{a}}$ Means \pm SE. The range of individual values is given in parentheses.
} 
resistant strain, PEG 87 and DuPont of $H$. virescence. Almost BRC strain responded to $10^{-9} \mathrm{M}$ of $\operatorname{cis}\left[{ }^{14} \mathrm{C}\right]$ cypermethrin, while $28 \%$ of PEG 87 and almost of Dupont responded to $10^{-7} \mathrm{M}$ of cis-cypermethrin. Also high metabolic ability and less penetration were observed. Also, McCaffery et al. $\left(1991^{b}\right)^{25)}$ studied with trans-and cis- $\left[{ }^{14} \mathrm{C}\right]$-cypermethrin for enzymes and resistance in Heliothis virescens. They compared one of susceptible stain, BRC and four different resistant strains, PEG 87 (lab), DuPont (lab), Itta Bena (field) and snook (field). they worked about metabolism of cypermethrin in vivo and in vitro studies trans $-\left[{ }^{14} \mathrm{C}\right]$-cypermethrin in $H$. virescens showed delayed uptake, and the compound was metabolized and excreted significantly faster in resistant PEG87 strain than in the susceptible BRC strain. They found that pretreatment with PBO (piperony butoxide) resulted in a reduction in the excretion of total radioactivity and conjugate from PEG87 larvae. In vitro metabolism study they observed that oxidative activity was located in the microsomes and was very clearly NADPH-dependent. Also, hydrolytic activity was found in all fractions such as $11,000 \mathrm{~g}$ supernatant. They identified 4'OH-cis-cypermethrin, cis- $\mathrm{Cl}_{2} \mathrm{CA}$, tOH-cis- $\mathrm{Cl}_{2} \mathrm{CA}$ and cis-Cl $\mathrm{CA}$-lac. They also measured the specific content of the cytochrome P-450 reductase for a number of strains of $H$. virescens, and certified that the elevation of the cytochrome P-450 specific contents indicates a mechanism of resistance.

Park et al $(1991)^{26)}$ studied with ${ }^{14} \mathrm{C}$-fenobucarb and ${ }^{14} \mathrm{C}$-carbofuran to investigate the cuticula penetration and detoxification of brown plnathopper (N. lugens stal). The brown plnathopper strains were selected with

Table 12. Metabolism of trans-cypermethrin by subcellular fractions prepared from 4th-instar larvae of PEG878 strain Heliothis virescens

\begin{tabular}{|c|c|c|c|c|c|c|}
\hline \multirow{3}{*}{ Fraction } & \multirow{3}{*}{ NADPH } & \multirow{3}{*}{$\begin{array}{l}\text { Incubation } \\
\text { time } \\
\text { (min) }\end{array}$} & \multicolumn{4}{|c|}{ Rate of formation of metabolites } \\
\hline & & & \multicolumn{2}{|c|}{ nmol min $^{-1}$ mg pretein ${ }^{-1}$} & \multicolumn{2}{|c|}{ nmol min $^{-1} \mathrm{mg}_{\text {insect }}{ }^{-1}$} \\
\hline & & & $t \mathrm{Cl} 2 \mathrm{Ca}$ & $2 \mathrm{OH} / 4 \mathrm{OH}$ & $t \mathrm{Cl} 2 \mathrm{CA}$ & $2 \mathrm{OH} / 4 \mathrm{OH}$ \\
\hline \multirow{3}{*}{$\begin{array}{c}11000 \mathrm{~g} \\
\text { supernaiant }\end{array}$} & - & 15 & 0.025 & 0.02 & 0.94 & 0.85 \\
\hline & + & 3 & 0.11 & 0.44 & 4.15 & 16.60 \\
\hline & + & 15 & 0.047 & 0.12 & 1.78 & 4.55 \\
\hline \multirow{3}{*}{ Microsomes } & - & 15 & 0.048 & $<0.01$ & 0.32 & 0.05 \\
\hline & + & 3 & 0.410 & 1.53 & 2.70 & 1.10 \\
\hline & + & 15 & 0.091 & 0.51 & 0.60 & 3.38 \\
\hline $\begin{array}{c}105000 \mathrm{~g} \\
\text { supernatant }\end{array}$ & - & 15 & 0.050 & - & 1.48 & - \\
\hline
\end{tabular}

Table 13. Isolation of some metabolites of ${ }^{14} \mathrm{C}$-carbofuran by thin layer chromatography after incubation with homogenates of the resistants $\left(R_{C}\right)$ and susceptible brown plnathopper strains

\begin{tabular}{ccc}
\hline Isolation & \multicolumn{3}{c}{ Isolation radiocarbon (\%) } \\
\cline { 2 - 3 } & $\mathrm{R}_{\mathrm{C}}$ & $\mathrm{S}$ \\
\hline 3-Hydroxycarbofuran & 0 & 0 \\
3-Hydroxycarbofuran phenol & 0 & 0.4 \\
3-Kotocarbofuran & 0.2 & 0.3 \\
Carbofuran & 72.4 & 81.1 \\
3-Ketocarbofuran phenol & 26.3 & 16.7 \\
Carbofuran phenol & 0.1 & 1.5 \\
Others & 1.0 & 0 \\
\hline
\end{tabular}


fenobucarb and carbofuran more than 18 generations. Each selected strains was designated $R_{f}$ and $R_{C}$ strains. Four day old female planthoppers were treated with chemicals topically on the dorsal thorax. From this study they observed that the rates of penetration were not significantly different in the susceptible and resistant strains, although over $50 \%$ of treated amount, of fenocucarb and carbofuran penetrated through cuticula within $1 \mathrm{hr}$ after treatment. However, total amount of excretion of the $R_{f}$ and $R_{c}$ strains were much higher than that of the susceptible strains. In vivo experiment they knew the resistant strains degraded chemicals for $2 \mathrm{hrs}$ faster than that of the susceptible one. They also found the major metabolites, OSBP (o-sec-butyl phenol) from fenobucarb and 3-keto carbofuran phenol from carbofuran. Total metabolite contents in resistant strain was nearly twice than in susceptible strains (Table 13).

\section{CONCLUSION}

It was reviewed that the research results using radio labelled insecticides performed by Korean researchers during 1981 2006. The papers were divided into 4 categories such as soil, plants, animals and insects.

Total 26 papers were reviewed as 12 in soil, 8 in plant, 7 in animal and 4 in insect area. Some papers covered both soil and plant. The staple interesting points of soil researches were the distribution of radio activities in organic and soluble fractions and in extractable and non-extractable fractions. Also the distributions in different organic matter fractions such as humic acid, fulvic acid and humin. And some papers dealt with metabolic pathway and metabolites. Rice was the major concerning plant using radio labeled insecticides. The uptake and distribution in each part of rice such as shoot and root, also the ratio of extractable and non-extractable portions were examined. In animal study, rat, mouse and carp were used for their purpose. And main concerning areas were distribution of radioactivity in different organs, and metabolic ability and metabolites, too. Also, mainly metabolic studies in view of resistance mechanism were performed with insects. Although it is not many researches using radio labelled insecticides, these papers are valuable to other researchers planning to use the radio labelled pesticides.

\section{REFERENCES}

1. Kim K. (1985) Fate of C-14 Labelled Diazinon in Rice Plants and Paddy soil. Master Thesis, The Graduate School, Seoul National University.

2. Lee S.K. (1985) Master Thesis, The Graduates School seoul National university, Fate of C-14 Labelled Diazinon in Rice Plants and Paddy Soil.

3. Park C.K. and S.R Oh (1986) Fate of C-14 labelled carbofuran in paddy plants and soil, Korean J. Environ. Agric. 5, 85-94.

4. Lee Y.D., K.H Lee, and C.K Park (1987) Fate of ${ }^{14} \mathrm{C}$-Carbofuran in Rice Plant and Paddy Soil, Korean J. Environ Agric. 6, 7-16.

5. Lee J.K. and K.S Oh (1993) Leaching Behavior of the Residues of Carbofuran, Bentazon, and TCAB in Soil, Korean J. Environ. Agric. 12, 9-17.

6. Lee Y.D. (1993) Absorption and Metabolism of Carbofuran in Soil, J. Agr. Sci., Taegu Univ. 7: 91-99.

7. Lee Y.D. and C.K Park (1995) Degradation of $\left[{ }^{14} \mathrm{C}\right]$ Carbofuran in Soils and Characterization of its Nonextractable Residues, Agricultural Chemistry and Biotechnology, 38(3), 263-268.

8. Lee J.K., K.S Kyung, J.W Kwon, K.C Ahn, and I.S Jung (1995) Behaviour of the Soil Residues of the Acaricide-InsecticideCultivation), $\left[{ }^{14} \mathrm{C}\right]$ Acrinathrin, (I. Behaviour during Crop (Maize) Korean J. Environ. Agric. 14(2), 189-201.

9. Lee J.K., K.S Kyung, and K.S Oh (1995 $)$ Behaviour of the Soil Residues of the Acaricide-Insecticide, $\left[{ }^{14} \mathrm{C}\right]$ Acrinathrin, (II. Degradation in Soil) Korean J. Environ. Agric. 14, 202-212.

10. Kim J.H., K.G Kang, C.K Park, K Kim, B.H Kang, S.K Lee, and J.K Roh (1998) Aerobic Soil Metabolism of Flupyrazofos, Pestic. Sci. 54, 237-243.

11. Ihm Y.B., K.S Kyung, C.S Kim, H-D Lee, G.H Ryu, and J.K Lee (2006) Adsorption and Leaching Characteristics of the Insecticide Imdacloprid in Paddy Soils, Korean J. of Environ. Agric. 25(1), 58-63.

12. Lee S.R. and Y.H Kim (1981) Behavior of ${ }^{14} \mathrm{C}-\mathrm{BHC}$ Residues in Rice Grain, J. of the Korean Nuclear Society, 13. 221-228.

13. Lee Y.D. $\left(1993^{b}\right)$ Absorption and Metabolism of $\left[{ }^{14} \mathrm{C}\right]$ Carbofuran by Rice Plants, J. Agr. Sci., Taegu Univ. 7:81-89.

14. Lee J.K., H.R Lee, K.S Kyung, and B.H Byun (1993) 
Elucidation of the translocation of phosphamidon used for the control of pine leaf gall midges (Thecodiplosis japonensis Uchida et lnouye) in the trunks of pine trees by means of a radiotracer. Part I. Trnaslocation as affected by pine tree species and the treated season, Hanguk Nonghwahak Hoechi (J. Korean Agric. Chem. Soc.), 36(6), 463-468.

15. Lee J.K., H.R Lee, and K.S Kyung (1993b) Elucidation of the translocation of phosphamidon used for the control of pine leaf gall midges (Thecodiplosis japonensis Uchida et Inouye) in the trunks of pine trees by means of a radiotracer. Part II. Metabolism in pine trees, Hanguk Nonghwahak Hoechi (J. Korean Agric. Chem. Soc.), 36(6), 469-475.

16. Kim I.S., K-B Lee, J.H Shim, and Y.T Suh (1995) In Vitro Metabolism Study of a-Endosulfan with Microsomal Cytochrome P-450 Monooxygenase System in Mouse, Agricultural Chemistry and Biotechnology, 38(5), 463-467.

17. Kim I.S., K.B Lee, J.H Shim, and Y.T Suh (1996) Metabolism of 14C-a-Endosulfan in Mouse in vivo, Korean J. Environ. Agric. 15, 70-76.

18. Han S.S. and Y.S Rim (1998) Effect of phenobarbital sodium and 3-methylcholanthrene on metabolism in vitro and toxicity of ${ }^{14} \mathrm{C}$-carbofuran in rat, The Korean J. of Pesticide Science, 2(2), 29-38.

19. Rim Y.S. and S.S Han (2002) Effect of Phenobarbital Sodium and 3-Methylcholan threne on Metabolism of ${ }^{14} \mathrm{C}$-carbofuran in Rat, Korean J. of Environmental Agriculture, 21(1), 57-68.

20. Lee K.B., J.H Shim, and Y.T Suh (1994) In vitro
Metabolism of Endosulfan in Carp (Cyprinus carpio), Agricultural Chemistry and Biotechnology, 37(3), 203-209.

21. Lee K.B., J.H Shim, and Y.T Suh (1994 $)$ Development of Radioimmunoassay (RIA) for Residue Analysis with Endosulfan in Water and Carp (Cyprinus carpio L.), Korean J. Environ. Agric. 13, 262-270.

22. Shin J.S., Y.D Lee, Y.K Kim, and Kenneth A. Lord (1997) Uptake, Biotransformation and Elimination of ${ }^{14} \mathrm{C}$-Fenobucarb by Carp (Cyprinus carpio), RDA. J. Crop Protec. 39(1):64-70.

23. Lee K.S., C.H. WALKER, A. McCAFFERY, M. AHMAD, AND E. LITTLE (1989) Metabolism of trans -Cypermethrin by Heliothis armigera and $H$. virescedns, Pesticide Biochemistry and Physiology 34, 49-57.

24. McCaffery Alan R., Colin H. Walker, Stephen E. Clarke, and K. Seung Lee (1991) Enzymes and resistance to insecticides in Heliothis virescens, Biochemical Society Transactions, 19, 762-767.

25. McCaffery Alan R., Richard T. Gladwell, Colin H. Walker, Stephen E. Clarke, and K-S Lee (1991 $1^{\text {b }}$ an international symposium on neuropharmacology and pesticide action - Mechanisms of Pyrethroid in Field and Laboratory Strains of Heliothis virescens, Pesticide Science, 32, 363-396.

26. Park H.M., Y.D Lee, and S.Y Choi (1991) The Adsorption and Metabolism of Fenobucarb and Carbofuran by Susceptible and Carbamate Insecticideselected Strains of the Brown Planthopper (Nilaparvata lugens Stal), Korean J. Appl. Entomol. 30(1):10-17. 